\title{
Naar bestuursgericht toezicht in de zorg: een zoektocht naar passendheid ${ }^{*}$
}

\author{
Annemiek Stoopendaal \& Hester van de Bovenkamp
}

\begin{abstract}
In dit artikel gaan we in op hoe toezicht op bestuur in de zorg het afgelopen decennium is vormgegeven. We beschrijven de vooronderstellingen achter deze beweging. Vervolgens laten we zien welke zoektocht heeft plaatsgevonden om toezicht op bestuur vorm te geven. Er was veel balanceerwerk nodig om tegemoet te komen aan de complexiteit van zorgbesturing. Dit komt doordat de externe druk op de toezichthouder na incidenten hoog is. Door deze druk moet er constant voor worden gewaakt bestuursgericht toezicht niet te versmallen tot toezicht op de bestuurder. Toezicht op goed bestuur vereist reflectiviteit van de inspecteurs en is gericht op het stimuleren van koppeling tussen bestuur en werkvloer. Daarvoor is experimenteerruimte nodig voor zowel bestuurders als toezichthouders. Om deze ruimte te bieden is niet alleen politiek en maatschappelijk debat noodzakelijk over de kwaliteit van zorg en de besturing ervan, maar ook aandacht en waardering voor de moeilijke afwegingen die daarbij horen.
\end{abstract}

\section{Inleiding}

In het toezicht op de zorg is een duidelijke ontwikkeling naar meer bestuursgericht toezicht te zien. De Inspectie Gezondheidszorg en Jeugd (IGJ), die toezicht houdt op de kwaliteit en veiligheid van zorg, heeft bestuursgericht toezicht al bijna een decennium op de toezichtagenda staan. Bestuursgericht toezicht werd in eerste instantie geduid als toezicht op de governance van kwaliteit van zorg. In 2009 identificeerde de IGJ (toen nog IGZ) dit thema als een structureel aandachtsgebied (IGZ, 2009). Een aantal incidenten rondom kwaliteit en veiligheid werd in die tijd geanalyseerd in termen van 'falende governance'. De analyse was dat raden van bestuur en raden van toezicht hun verantwoordelijkheid voor de kwaliteit van zorg onvoldoende oppakten (OvV, 2008; 2011; 2014; Behr, Grit, Robben, \& Bal, 2015). Ook vanuit het ministerie van Volksgezondheid, Welzijn en Sport (VWS) werd in reactie op deze kwaliteitsincidenten de eindverantwoordelijkheid voor de kwaliteit van zorg van de raden van bestuur benadrukt (Klink, 2009; Schippers \& Van Rijn, 2013).

Vanuit media en politiek volgde een terugkerende roep om meer en strenger toezicht op de kwaliteit van zorg en de besturing daarvan. Dit laatste wordt vaak vertaald naar toezicht op de persoon van bestuurders. Dit zagen we bijvoorbeeld in het geval van de ouderenzorg in de discussie die werd aangezwengeld rondom de

* Dr. A.M.V. Stoopendaal is Assistant Professor aan de Erasmus School of Health Policy \& Management Health Care Governance. Dr. H.M. van de Bovenkamp is Associate Professor aan de Erasmus School of Health Policy \& Management Health Care Governance. 
zorg voor de moeder van voormalig staatssecretaris Van Rijn, waar zorgbestuurders verantwoordelijk werden gesteld voor de matige kwaliteit van zorg die in verpleeghuizen geleverd werd. ${ }^{1}$ In het manifest 'Scherp op ouderenzorg' wordt gepleit voor een verplichte ballotage voor bestuurders en toezichthouders. ${ }^{2}$ Ook worden er regelmatig Kamervragen gesteld over de salarissen van zorgbestuurders $^{3}$ en worden uitspraken van bestuurders onder een vergrootglas gelegd. ${ }^{4}$

Toezicht op de besturing van zorg is echter een lastige opgave. Het levert vragen op als: Wanneer schiet het bestuurlijk vermogen tekort of is het bestuurlijk gedrag onprofessioneel? Wanneer is een zorgbestuurder te vertrouwen? Wanneer kan de besturing van een zorginstelling worden geduid als Goed Bestuur? Deze vragen zijn lastig te beantwoorden. Ten eerste omdat grote zorgorganisaties complexe organisaties zijn en de gezondheidszorg een complexe omgeving is. Ten tweede omdat besturen inherent relationeel en contextueel is (Pittens, Zonneveld, Vermunt, \& Minkman, 2018; Van der Scheer, 2018). Bestuurders zijn maar enkele spelers in een gelaagd veld, waarin met veel verschillende verwachtingen rekening gehouden moet worden. Vanuit deze verschillende perspectieven krijgt dat wat als Goed Bestuur wordt gezien steeds een andere invulling (Van de Bovenkamp, Stoopendaal, \& Bal, 2017). Daarbij zijn organisaties zelf ook gelaagd en is besturing gedistribueerd over meerdere actoren binnen de organisatie (Pittens, Zonneveld, Vermunt, \& Minkman, 2018). Erkenning van deze complexiteit verhoudt zich echter moeizaam tot de maatschappelijke en politieke druk op de inspectie om vanuit een helder, eenduidig kader risico's in de zorg tegen te gaan. Dit maakt het vormgeven van bestuursgericht toezicht in de zorg tot een zoektocht voor de toezichthouder.

In dit artikel beschrijven we deze zoektocht van de IGJ om op een passende manier toezicht te houden op de besturing van zorg. Wij baseren ons op verschillende onderzoeken die wij in de afgelopen zes jaar hebben uitgevoerd, merendeels in het kader van de Academische Werkplaats Toezicht van de IGJ. ${ }^{5}$ Vanuit deze onderzoeken geven we een longitudinaal perspectief op de ontwikkeling van bestuursgericht toezicht in de zorg. We beschrijven de achtergronden en vooronderstellingen van dit toezicht en de ervaringen ermee. In onze conclusie

1 Zie https://www.rtlnieuws.nl/gezondheid/kamer-weg-met-de-falende-zorgbestuurders.

2 Zie https://www.scherpopouderenzorg.nl.

3 Zie https://www.volkskrant.nl/nieuws-achtergrond/kamer-kabinet-moet-zorgbestuurdersaanspreken-op-verhoging-salaris b50f4f99/.

4 Zie https://www.trouw.nl/samenleving/personeel-verpleeghuis-de-leeuwenhoek-wil-excuses-nauitspraak-voorzitter acf89f9a/.

5 Dit onderzoek startte met een formatief onderzoek naar een experiment met systeemtoezicht (Stoopendaal \& De Bree, 2014; Stoopendaal, De Bree, Robben, \& Keuter, 2014; Stoopendaal, De Bree, \& Robben, 2016; Stoopendaal, 2016). Vervolgens hebben we bestudeerd hoe bestuur vorm krijgt in de gelaagde context van zorg (Stoopendaal \& Van de Bovenkamp, 2015a\&b; Van de Bovenkamp, Stoopendaal, \& Bal, 2017). Hierna is het project Goed Bestuur van de IGJ gevolgd met observationeel/etnografisch onderzoek (Stoopendaal, 2016) en is het vertrouwen dat ondertoezichtstaanden hebben in de IGJ onderzocht (Stoopendaal \& Bouwman, 2018). Tot slot hebben we onlangs onderzoek gedaan naar reflectieve sturing in de ouderenzorg (Van de Bovenkamp, Stoopendaal, Oldenhof, \& Bal, 2017; Van de Bovenkamp, Stoopendaal, Van Bochove, Hoogendijk, \& Bal, 2018). 
geven we richtingen aan waarin het bestuursgericht toezicht in de zorg zich zou kunnen ontwikkelen, om zo bij te dragen aan betere kwaliteit van zorg. We bepleiten daarbij het belang van responsief toezicht.

\section{De vooronderstellingen achter bestuursgericht toezicht in de zorg}

Het uitgangspunt van de beweging naar bestuursgericht toezicht in de zorg berust op de erkenning dat raden van bestuur eindverantwoordelijk zijn voor de organisatie (vormgeving) van kwalitatief goede en veilige zorg. Dit is vastgelegd in de Kwaliteitswet zorginstellingen (Kwz 1996) (Legemaate et al., 2013, pp. 34 en 59). De omslag van overheidsregulering naar zelfregulering, gevolgd door de invoering van een stelsel gebaseerd op marktwerking, creëerde het besef bij toezichthouders dat niet alleen professionals, maar ook bestuurders verantwoordelijk zijn voor de kwaliteit van zorg. De bestuurlijke verantwoordelijkheid werd steeds meer benadrukt in publieke debatten, met name na kwaliteitsincidenten in de zorg (Legemaate et al., 2013; Behr, Grit, Robben, \& Bal, 2015).

De veronderstelling van toezichthouder en overheid is dat door middel van bestuursgericht toezicht, mits op een manier ingericht die recht doet aan de meervoudigheid van zorg, beter zicht kan worden verkregen op de kwaliteit van zorg, de veiligheid, en op de verbeterinitiatieven daarvan (IGZ, 2011; Schippers \& Van Rijn, 2016). De aanname is dat deze focus van het toezicht kan leiden tot een reductie van de toezichtlast. Immers, waar de interne systemen en governance inzichtelijk geregeld zijn en goed werken, hoeft het externe toezicht minder gedetailleerd te zijn (Gilad, 2011; Heimer, 2011; Stoopendaal, De Bree, \& Robben, 2016). Toezicht zou op deze manier vruchtbaarder worden (Jerak-Zuiderent, 2013). Het geeft dan namelijk niet alleen zicht op de organisatie van zorg, maar draagt ook bij aan het leren verbeteren van de kwaliteit van zorg, doordat mogelijke verbeterpunten in dialoog naar voren komen (Halsema, Van Februari, Kalleveen, \& Terpstra, 2013; Stoopendaal \& Bouwman, 2018).

Tegelijkertijd bestaat er een beweging met een andere veronderstelling, namelijk dat de inspectie door streng optreden na incidenten risico's kan beheersen. Zorgorganisaties moeten aantonen dat zij verantwoorde zorg bieden en de inspectie moet daarop toezicht houden. Bij beide partijen creëert dit een behoefte aan instrumenten die de kwaliteit van zorg zichtbaar maken. Vanuit deze meer restrictieve invalshoek werd het nodig geacht de kwaliteit van zorg zichtbaar en daarmee controleerbaar te maken. Door de focus op transparantie werd er meer nadruk gelegd op instrumenten om de kwaliteit van zorg te meten. Kwaliteitsindicatoren zijn daarin een belangrijke rol gaan vervullen (Legemaate et al., 2013; Van de Bovenkamp, De Mul, Quartz, Weggelaar-Jansen, \& Bal, 2014). Door de combinatie van marktwerking en toenemende transparantie kwamen meer kwaliteitsincidenten aan het licht. In reactie op politieke en maatschappelijke druk kwam de overheid met een aanscherping en uitbreiding van regelgeving om incidenten in de toekomst te voorkomen. Zorgaanbieders werden verplicht voorgevallen calamiteiten bij de inspectie te melden en de IGJ ging zich naast het risicotoezicht op basis van de kwaliteitsindicatoren ook richten op incidententoezicht 
naar aanleiding van meldingen. Hoewel er dus enerzijds veel nadruk werd gelegd in het beleid op zelfregulering en bestuursgericht toezicht om die te controleren, probeerde de overheid anderzijds via het risico- en incidententoezicht meer grip te krijgen op de kwaliteit van zorg (Van Twist, Klijn, \& Van der Steen, 2013; Leegemate et al, 2013).

Er zit kortom een tweeslachtigheid in de vooronderstellingen achter het toezicht op de kwaliteit van zorg. Daar komt nog bij dat zorgaanbieders te maken hebben met een veelheid aan actoren naast de IGJ (zoals verzekeraars, zorgkantoren, brancheorganisaties, patiëntenorganisaties, Nederlandse Zorgautoriteit (NZa)), die met behulp van verschillende instrumenten ook grip proberen te krijgen op de kwaliteit van zorg die wordt geleverd binnen hun organisatie. Al deze activiteiten en partijen hebben geleid tot fragmentatie, regeldruk en steeds gulziger toezicht (vrij naar Trommel, 2009; Van de Bovenkamp, De Mul, Quartz, Weggelaar-Jansen, \& Bal, 2014; Van de Bovenkamp, Stoopendaal, Van Bochove, Hoogendijk, \& Bal, 2018). De complexiteit wordt verder versterkt door het veelvormige karakter van zorg, waardoor professionals soms juist moeten afwijken van richtlijnen om goede zorg te leveren. Daarvoor is regelruimte nodig, die door de nadruk op beheersing van kwaliteit en veiligheid door externe partijen is ingeperkt (Van de Bovenkamp, Stoopendaal, Van Bochove, Hoogendijk, \& Bal, 2018). De tweeslachtigheid in de vooronderstellingen over het toezicht op de kwaliteit van zorg heeft consequenties voor hoe het bestuursgericht toezicht vorm heeft gekregen in deze sector. We gaan hier in de volgende paragraaf op in.

\section{Beleidsmatige ontwikkeling van bestuursgericht toezicht in de zorg}

In deze paragraaf beschrijven we de zoektocht in de ontwikkeling van het bestuursgericht toezicht in de zorg. Een zoektocht waarin geprobeerd is de complexiteit van zorgbesturing te onderkennen en waarbij de druk, voortkomend uit de nadruk op het vermijden van risico's en incidenten, op het toezicht groot was om juist de blik te vernauwen.

Een eerste poging tot een beleidsmatige inkadering van het toezicht op zorgbestuur doet de IGJ in 2011 met het toezichtkader 'Bestuurlijke verantwoordelijkheid voor kwaliteit en veiligheid'. Hierin werd gesteld dat de IGJ vooralsnog de governancestructuur van een instelling niet als geïsoleerd onderwerp zal beoordelen. Het werd echter niet uitgesloten dat zij in de toekomst (onderdelen of aspecten van) de governancestructuur als onderwerp van onderzoek zou gaan selecteren, wanneer daar vanuit het belang van de kwaliteit en veiligheid van de zorg aanleiding toe zou zijn (IGZ, 2011).

In de jaren daarna neemt de IGJ verschillende initiatieven om bestuursgericht toezicht handen en voeten te geven. Zo startte de IGJ in 2012 met het operationaliseren van toezicht op de besturing van grotere zorginstellingen door middel van het project Systeem Toezicht (ST). ST gaat ervan uit dat wanneer bestuurders en raden van toezicht hun verantwoordelijkheid nemen, het publieke toezicht op de naleving beperkt kan worden tot toezicht op (de werking van) het zelf opgezette 'systeem' om kwaliteit en veiligheid te borgen en risico's te beheersen. In het 
ST-project is er geëxperimenteerd met toezicht volgens dit idee. Bestuurders werd gevraagd te presenteren hoe zij sturen op kwaliteit. Het inspectiebezoek startte vanuit deze open vraag. Dit benadrukte de eigen verantwoordelijkheid van bestuurders en gaf hun ruimte de eigen keuzes in de besturing te verantwoorden. In dit project werd het toezicht gericht op de besturing van zorg breed opgevat door niet alleen wanneer er een incident of calamiteit heeft plaatsgevonden de besturing onder de loep te nemen (Stoopendaal \& De Bree, 2014; Stoopendaal, De Bree, Robben, \& Keuter, 2014; Stoopendaal, De Bree, \& Robben, 2016).

De ervaringen van zowel de IGJ als de ondertoezichtgestelden met het project ST waren positief (meer hierover in de volgende paragraaf). De uitkomsten werden door de IGJ echter niet direct opgepakt. Dit had een aantal redenen. Ten eerste paste ST niet in de tweedeling van risicotoezicht en incidententoezicht. Voor het experiment waren namelijk zes goed functionerende zorginstellingen uit verschillende zorgsectoren uitgekozen waar vanuit het risicotoezicht normaal gesproken geen bezoek zou worden afgelegd. Ten tweede zorgde de eerder beschreven politieke druk om strenger toe te zien voor spanning. ST leek hier haaks op te staan, door de focus op organisaties waar het goed ging en op vertrouwen en loslaten. ${ }^{6}$ Ten derde was in de zorg een bredere discussie over de inhoud van zorg en het toezicht daarop gaande. Men verguisde de systeem-wereld, waartoe toezichthouders en managers horen, en omarmde de waarde van de leefwereld. (zie ook Schippers \& Van Rijn, 2013). Het begrip systeem werd daarmee een te beladen begrip in de zorg (Stoopendaal, 2016).

In 2015 vervolgde de IGJ haar zoektocht naar bestuursgericht toezicht. Het begrip systeemtoezicht werd ingeruild voor het positiever klinkende 'Toezicht op Goed Bestuur'. Opnieuw werd hiermee geëxperimenteerd in een project (Stoopendaal, 2016). De opdracht vanuit VWS was om samen met de NZa een toezichtkader Goed Bestuur (IGJ \& NZa, 2016) te onwikkelen. In het toezichtkader werd geprobeerd een brede blik op zorgbestuur in normen te vatten en daarmee recht te doen aan de complexiteit daarvan. De focus van het toezicht werd geordend door middel van de triade: resultaten, gedrag \& cultuur en systemen. Kwaliteit en veiligheid in de zorg werden in dit project niet meer alleen gezien als een te meten of systematisch te organiseren entiteit, maar ook als een sociaal (besturings)proces. Het toezichtkader werd geaccordeerd door de minister en toegevoegd aan het beleidskader 'Goede zorg vraagt om goed bestuur' (Schippers \& Van Rijn, 2016).

Anders dan in het experiment ST, lag in het project Goed Bestuur de focus niet op goed functionerende instellingen. Hoewel de titel van het project dat wel doet denken, werden bestuursgesprekken juist gevoerd wanneer de IGJ zorgen had over de besturing van de betreffende instelling. De bestuursgesprekken die in het toezicht op de ouderenzorg werden ingevoerd, werden daardoor bijvoorbeeld bestraffend of handhavend van aard. Zo werd een koppeling gevonden met risicogestuurd toezicht, waardoor dit toezicht meer (dan ST) binnen de kaders van de

6 Dit was een onterechte aanname, daar de IGJ in het ST-project niet alleen informatie verzamelde over het systeem, maar ook over de uitkomst van de zorg, en zo nodig streng kon handhaven. 
IGJ viel. Deze aanpak veranderde echter in de loop van het project. In een latere fase werden de bestuursgesprekken gebruikt om het toezichttraject te starten en werden de inspectiebezoeken gestart met een open gesprek tussen bestuurders en (interne en externe) toezichthouders. Hierdoor is een meer gebalanceerde manier van werken ontstaan, die zowel waarderend als waarschuwend kan zijn.

De volgende stap die de IGJ zette, was het ontwikkelen van een afwegingskader Vertrouwen (Spronk, Buijze, Zwietering, Friele, \& Robben, 2017). Dit kader helpt de inspecteurs te beoordelen wanneer ruimte kan worden geboden aan bestuurders om aan hun verantwoordelijkheid voor kwaliteit tegemoet te komen. Met het toezichtkader Goed Bestuur laten de toezichthouders zien aan de ondertoezichtstaanden wat zij verstaan onder goede zorgbesturing en wat zij doen om dit te bevorderen. Met het afwegingskader Vertrouwen kunnen inspecteurs vervolgens hun vertrouwen in een zorgaanbieder expliciteren en onderbouwen.

Hoewel zowel in het toezichtkader Goed Bestuur als in het afwegingskader Vertrouwen aandacht is voor zorgbesturing als relationeel en situationeel gegeven dat sterk gekoppeld is aan de wijze waarop kwaliteit van zorg is ingericht, blijft de neiging bestaan om de focus te versmallen naar toezicht op de bestuurder. Dit is ingegeven door de inbedding van bestuurstoezicht in risicotoezicht, waarmee de nadruk komt te liggen op het vermijden van risico's en incidenten. Zo gaan er binnen de IGJ nu stemmen op om, als een vervolgstap in het bestuursgericht toezicht, een instrument te ontwikkelen dat mogelijkheden biedt het gedrag van de bestuurder te beoordelen, om zo incidenten te kunnen voorkomen. Besturing dreigt daarmee onterecht te worden versimpeld tot een enkele actor in plaats dat in ogenschouw wordt genomen dat besturing zich ontwikkelt vanuit het samenspel tussen vele actoren in een gelaagde context.

\section{Ervaringen met bestuursgericht toezicht}

De ontwikkeling van bestuursgericht toezicht in de zorg laat de zoektocht van de IGJ zien naar het samenbrengen van verschillende verwachtingen van het toezicht: het ruimte bieden aan de complexiteit van zorgbestuur en de focus op het voorkomen van risico's en incidenten door het streng reguleren van de zorg. In deze paragraaf exploreren we eerst de uitwerking van bovenbeschreven ontwikkelingen op het bestuursgericht toezicht. Daarna richten we ons meer specifiek op de vorm die bestuursgericht toezicht, in navolging op de hierboven beschreven experimenten, in de ouderenzorg heeft gekregen.

\section{Ont- en herkoppeling tussen bestuur en werkvloer}

Uit het onderzoek naar het experiment met ST kwam naar voren dat deze manier van toezicht houden de ontkoppelingen tussen bestuur en werkvloer blootlegt (De Bree \& Stoopendaal, te verschijnen). Dat is een belangrijke toegevoegde waarde van dit type toezicht. Ontkoppeling ontstaat wanneer actoren op verschillende niveaus niet voldoende op de hoogte zijn van of aansluiten bij elkaars werkzaamheden en ervaringen. Het werk zoals dat wordt voorgesteld in 
beleidsplannen van een instelling is dan anders dan hoe het daadwerkelijk wordt uitgevoerd. Zo kan beleid worden ontwikkeld dat op de werkvloer niet praktisch blijkt te zijn, of kunnen er regels worden gemaakt die niet passen bij de dagelijkse zorgverlening. In die gevallen treedt vaak een proces op waarin ofwel regels worden genegeerd, ofwel regels als doel worden gezien en niet meer als middel om goede zorg te bereiken. In dat geval hebben bestuurders maar beperkt de controle over kwaliteit van zorg. Herkoppeling betekent dat er juist aansluiting wordt gezocht en gevonden tussen de niveaus van de organisatie, discussies over kwaliteit van zorg tussen verschillende niveaus worden samengebracht en er samen naar oplossingen gezocht wordt (Bromley \& Powell, 2012). Door de observaties van de inspecteurs te bespreken werden in het ST-project zowel bestuurders als zorgverleners zich bewust van eventuele ontkoppelingen, waarbij de uitvoering anders bleek dan in beleid was vastgelegd of werd gedacht. Daar waar beleid en uitvoering zijn ontkoppeld, is sturing eigenlijk niet mogelijk (De Bree \& Stoopendaal, 2018).

Bij latere bezoeken die wij aflegden bij de in het experiment betrokken zorginstellingen bleek dat bewustwording van ontkoppeling veelal leidde tot verbeteringen in de afstemming tussen beleid en uitvoering. Deze afstemming leidt vervolgens tot een beter kwaliteitssysteem en daarmee tot betere kwaliteit van zorg (Van Schoten, 2015; Botje, 2017). De inspectiebezoeken in het ST-project, zo leerden we, zetten sterk aan tot leren. Door de meer op open dan op gesloten normen gebaseerde manier van bevragen kunnen inspecteurs in het toezicht op zorgbesturing de samenhang tussen uitkomsten van zorg, gedrag en cultuur en systemen blootleggen en prestaties van de zorginstelling aan hun eigen ambities en kwaliteitsdoelstellingen toetsen. Belangrijk is ook dat de bevindingen worden geduid in een gesprek tussen inspecteurs, zorgverleners en zorgbestuurders. Dit zijn belangrijke bevindingen in het licht van recente vernieuwingen van het toezicht op de ouderenzorg, die veel gemeen hebben met de in het experiment beproefde werkwijze.

\section{Ervaringen met bestuursgericht toezicht in de ouderenzorg}

Vanaf begin 2017 heeft de IGJ in het toezicht op de ouderenzorg aandacht voor zowel de besturing als de specifieke en ingewikkelde zorg voor ouderen. Het nieuwe toetsingskader (Modulair Kern Instrument, MKI) is gebaseerd op het nieuwe kwaliteitskader verpleeghuiszorg (2017), dat weer is gebaseerd op drie pijlers: persoonsgerichte zorg, deskundigheid en inzet personeel en sturen op kwaliteit en veiligheid (systemen en cultuur). Om iets over deze pijlers te zeggen observeren de inspecteurs in de zorg en voeren zij gesprekken met bestuurders, medewerkers, (kwaliteits)managers, behandelaren en cliëntvertegenwoordigers. Zo nodig wordt extra aandacht gegeven aan de kwaliteitsthema's die gezien worden als te meten basiskwaliteit (zoals bijvoorbeeld medicatieveiligheid). Tijdens dit toezicht is er aandacht voor het feit dat het niet altijd even gemakkelijk vast te stellen is wat goede kwaliteit van ouderenzorg is. Sommige bestuurders besteden bijvoorbeeld veel tijd en energie aan het organiseren van persoonsgerichte zorg. Om die te kunnen leveren kan het zijn dat ze niet voldoen aan bepaalde extern vastgelegde regels als de wensen van bewoners daar niet mee te rijmen zijn (Van 
de Bovenkamp, Stoopendaal, Van Bochove, Hoogendijk, \& Bal, 2018). In de ouderenzorg is op deze manier meer aandacht gekomen voor de persoonsgerichtheid van de zorg en de eigen keuzes hierin van de zorgaanbieder. Het vraagt flexibiliteit van de toezichthouder om deze afwegingen te beoordelen en zo recht te doen aan de pluriformiteit van zorg, en daarmee aan de kwaliteit van zorg. Deze manier van toezicht houden kan daarmee worden gezien als het creëren van passendheid (Meurs, 2014). Passendheid betekent ook dat er naast het tellen (de vinkenlijstjes) aandacht is voor vertellen: zorgorganisaties krijgen de ruimte om te vertellen en uiteen te zetten hoe ze werken aan kwaliteit van zorg en hoe ze deze meer persoonsgericht maken. Daarbij ligt de focus niet alleen op zorgbestuurders, maar op alle lagen van de organisatie en wordt gekeken hoe verschillende lagen binnen de organisatie aan elkaar gekoppeld worden. Bovendien wordt beter bij de context en de eigen keuzes van het toezichtobject aangesloten.

De ervaringen met het gebruik van het nieuwe toetsingskader zijn positief volgens het eigen onderzoek van de IGJ (IGJ, 2018), maar ook volgens respondenten uit zorginstellingen die ervaren hebben hoe dit nieuwe toezicht in de ouderenzorg wordt uitgevoerd (Zorgvisie 19 april 2018; De Graaff, 2018; Stoopendaal \& Bouwman, 2018). Vooral de ruimte om uit te leggen hoe er aan kwaliteit wordt gewerkt en waarom het soms nodig is om van bepaalde regels af te wijken, kan op waardering van het veld rekenen. Klaarblijkelijk doet deze manier van toezicht houden meer recht aan de complexiteit van zorgverlening en het bestuur daarvan in de ouderenzorg (Van de Bovenkamp, Stoopendaal, Van Bochove, Hoogendijk, \& Bal, 2018).

\section{Bestuursgericht toezicht vereist responsiviteit, dialoog en experimenteerruimte}

Het idee dat Goed Bestuur te normeren zou zijn in een toetsbaar normenkader lijkt een heilloze weg, omdat zorgbesturing inherent situationeel en relationeel is (Pittens, Zonneveld, Vermunt, \& Minkman, 2018; Van der Scheer, 2018). In plaats daarvan moeten toezichthouders erop toezien dat ervaringen en prestaties worden gemonitord en dat daarover verantwoording wordt afgelegd. De aandacht verschuift daarbij naar de invulling die raden van bestuur geven aan hun verantwoordelijkheid voor de kwaliteit van zorg en stelt hun de vraag te laten zien hoe zij goede zorg organiseren. ${ }^{7}$

Bestuursgericht toezicht vergt toezicht waarbij openheid en leren vooropstaan. Dit wordt ook wel 'Smart Regulation' genoemd, dat - in plaats van op het gestructureerd volgen van een voorgevormde reeks aan instrumenten voor toezicht en handhaving - de nadruk legt op pluriformiteit, flexibiliteit en complementariteit van regulatieve instrumenten (Gunningham, Grabosky, \& Sinclair, 1998; Baldwin \& Black, 2008; Gunningham \& Sinclair, 2017).

7 Het betrekken van de raden van toezicht is een mogelijk productieve toevoeging op de informatieverzameling door de IGJ, maar hiermee is nog niet voldoende geëxperimenteerd (Schakel \& Stoopendaal, 2017). 
Het in ogenschouw nemen van de complexe context waarin ondertoezichtstaanden functioneren, vereist responsiviteit. Responsiviteit wordt vaak gedefinieerd als het inzetten van regulatieve instrumenten die passen bij het onderwerp waarop toezicht moet worden gehouden (Ayres \& Braithwaite, 1992). Maar responsiviteit betekent ook oog hebben voor de specifieke situatie waarin de ondertoezichtstaande zich bevindt. Responsiviteit krijgt zo de betekenis van flexibiliteit en terugkoppeling (Kagan \& Bardach, 1982). Toezicht wordt dan een interactief proces, waarbij ook de toezichthouder openstaat voor vragen of klachten, in gesprek gaat met belanghebbenden en door middel van lerend vermogen het eigen handelen aanpast, waardoor de kwaliteit van het toezicht kan verbeteren (De Vries, 2016; Bokhorst \& Van Erp, 2017; Rutz, 2017). Het functioneren van de toezichthouder is inzichtelijk gemaakt, waarna de bevindingen en ervaringen vanuit het inspectiebezoek geduid worden in een betekenisvol gesprek, waardoor duidelijk kan worden hoe de zorg en het bestuur, maar ook het toezicht daarop te verbeteren zou zijn.

Deze manier van toezicht houden doet recht aan de positie waarin zorgbestuurders zich bevinden en vraagt om experimenteerruimte voor zowel toezichthouders als bestuurders, waarbij externe partijen, zoals de IGJ, zoeken naar mogelijkheden om reflectie in de praktijk te bevorderen (Sabel \& Zeitlin, 2008 Oldenhof \& Bal, 2016.

\section{Conclusie}

Bestuursgericht toezicht kan in de zorg rekenen op brede belangstelling. Dit artikel laat zien dat er op dit vlak veel ontwikkeling heeft plaatsgevonden de laatste jaren. Uit deze beschrijving valt op te maken dat dit echter geen gemakkelijke opgave is om in de praktijk te brengen. Maatschappelijke en politieke druk en de focus van het toezicht op het tegengaan van risico's en incidenten maken het ingewikkeld om bestuursgericht toezicht op een effectieve manier vorm te geven. Via de projecten ST en Toezicht op Goed Bestuur, de ontwikkeling van het afwegingskader Vertrouwen en het toezichtkader ouderenzorg heeft de IGJ vorm gegeven aan meer bestuursgericht toezicht. Het zoeken naar passend bestuursgericht toezicht was geen rechtlijnig, maar eerder een rommelig proces, waar nieuw denken en doen werden uitgeprobeerd in een experimentele 'ruimte'.

Bestuursgericht toezicht in de zorg kan, wanneer dat op een slimme en responsieve manier gebeurt, door het stimuleren van herkoppelen en wederzijds leren, een positieve bijdrage leveren aan de kwaliteit van zorg. Tegelijkertijd moet bestuursgericht toezicht niet als heilige graal worden gezien en niet tot de bestuurder alleen worden vernauwd. Er zijn veel partijen betrokken bij het maken van de kwaliteit van zorg. Juist de interacties tussen verschillende lagen binnen en buiten de organisatie bepalen de kwaliteit van zorg die geleverd kan worden. Omdat de IGJ toezicht houdt op de kwaliteit en veiligheid van zorg moet dát altijd het uitgangspunt voor het toezicht zijn. Immers, de relatie tussen goed bestuur en goede zorg is niet zo rechtlijnig. 


\section{Literatuur}

Ayres, I., \& Braithwaite, J. (1992). Responsive regulation: Transcending the deregulation debate. Oxford: Oxford University Press.

Baldwin, R., \& Black, J. (2008). Really responsive regulation. The Modern Law Review, 71, 59-94. doi:10.1111/j.1468-2230.2008.00681.x

Behr, L., Grit, K., Robben, P., \& Bal, R. (2015). Framing and re-framing critical incidents in hospitals. Health, Risk \& Society. doi:10.1080/13698575.2015.1006587

Bokhorst, M., \& Erp, J. van. (2017). Van transparantie naar responsiviteit. Ontwikkeling van de omgevingsgerichtheid van toezichthouders. Utrecht: Utrechtse School voor Bestuur en Organisatie.

Botje, D. (2017). From the boardroom to the bedside and back. Utrecht: NIVEL.

Bovenkamp, H.M. van de, Stoopendaal, A.M.V., \& Bal, R. (2017). Working with layers: The governance of regulation of healthcare quality in an institutionally layered system. Public Policy and Administration, 32(1), 45-65. doi:10.1177/0952076716652934

Bovenkamp, H.M. van de, Stoopendaal, A.M.V., Oldenhof, L.E., \& Bal, R.A. (2017). Eigen regie, regeldruk en regelruimte. iBMG.

Bovenkamp, H.M. van de, Mul, M. de, Quartz, J.G.U., Weggelaar-Jansen, J.W.M., \& Bal R.A. (2014). Institutional layering in governing healthcare quality. Public Administration, 92(1), 208-223.

Bovenkamp, H.M. van de, Stoopendaal, A.M.V., Bochove, M. van, Hoogendijk, H., \& Bal R.A. (2018). Persoonsgerichte zorg, regeldruk en regelruimte: van regelreflex naar spiegelreflex. ESHPM, Rotterdam.

Bree, M. de, \& Stoopendaal, A. (2018). De- and recoupling and public regulation. Organization Studies. Doi: 10.1177/0170840618800115

Bromley, P., \& Powell, W.W. (2012). From smoke and mirrors to walking the talk: Decoupling in the contemporary world. Academy of Management Annals, 6(1), 483-530.

Gilad, S. (2011). Process-oriented regulation: Conceptualization and assessment. In D. LeviFaur (Ed.), Handbook on the politics of regulation (pp. 423-438). Cheltenham: Edward Elgar.

Graaff, B. de. (2018). Toezicht, ervaring en deskundigheid: een evaluatie van de inzet van ervaringsdeskundigen in het toezicht op de ouderenzorg. Een begeleidend onderzoek naar het project 'Ervaringsdeskundigen'. ESHPM, Rotterdam.

Gunningham, N., \& Sinclair, D. (2017). Leaders and laggards: Next-generation environmental regulation. London: Routledge.

Gunningham, N., Grabosky, P.N., \& Sinclair, D. (1998). Smart regulation: Designing environmental policy. Oxford: Oxford University Press.

Halsema, F., Februari, M. van, Kalleveen, M., \& Terpstra, D. (2013). Een lastig gesprek. Advies commissie behoorlijk bestuur. Den Haag.

Heimer, C.A. (2011). Disarticulated responsiveness: The theory and practice of responsive regulation in multi-layered systems. University of British Columbia Law Review, 44(3), 663-693.

IGJ. (2018). Hoe bevalt het nieuwe toezicht ouderenzorg en gehandicaptenzorg? Verkregen van https://www.igj.nl/documenten/publicaties/2018/04/18/hoe-bevalt-het-nieuwetoezicht-ouderenzorg-en-gehandicaptenzorg

IGJ \& NZa. (2016). Kader toezicht op Goed Bestuur. Verkregen van https://www.igj.nl/ documenten/publicaties/2016/07/06/kader-toezicht-op-goed-bestuur

IGZ. (2009). De vrijblijvendheid voorbij. Sturen en toezichthouden op kwaliteit. In Staat van de Gezondheidszorg 2009. Inspectie voor de Gezondheidszorg, Den Haag. 
IGZ. (2011). Toezichtskader 'Bestuurlijke verantwoordelijkheid voor kwaliteit en veiligheid'. Verkregen van http://docplayer.nl/6912519-Toezichtkader-bestuurlijkeverantwoordelijkheid-voor-kwaliteit-en-veiligheid.html

Jerak-Zuiderent, S. (2013). Generative accountability: Comparing with care. Dissertatie, Erasmus Universiteit Rotterdam, Rotterdam.

Kagan, R.A., \& Bardach, E. (1982). Going by the book: The problem of regulatory unreasonableness. Philadelphia: Temple University Press.

Klink, A. (2009). Ruimte en rekenschap voor zorg en ondersteuning. Ministerie van Volksgezondheid, Welzijn en Sport, Den Haag.

Legemaate, J., Grit, K., Plomp, E., Die, M. de, Bovenkamp, H. van de, Broer, T., Bouwman, R., Bomhoff, M., Friele, R., \& Bal, R. (2013). Thematische wetsevaluatie Bestuursrechtelijk toezicht op kwaliteit van zorg. Den Haag: ZonMw.

Meurs, P. (2014). Van regeldruk naar passende regels. Vertrouwen, veerkracht, verantwoordelijke vrijheid. Den Haag.

Oldenhof, L., \& Bal, R. (2016). Voorbij de kloof tussen systeem en leefwereld: een zoektocht naar goede leefsystemen met experimentele governance. In: Verlangen naar samenhang. Over systeemverantwoordelijkheid en pluriformiteit. Den Haag: Raad voor Volksgezondheid \& Samenleving.

OvV. (2008). Een onvolledig bestuurlijk proces: hartchirurgie in UMC St Radboud. Onderzoek naar aanleiding van berichtgeving op 28 september 2005 over te hoge mortaliteit. Den Haag: Onderzoeksraad voor Veiligheid.

OvV. (2011). Vernieuwing op drift: onderzoek naar aanleiding van berichtgeving in april 2009 over calamiteiten bij maagverkleiningsoperaties in het Scheper ziekenhuis Emmen. Den Haag: Onderzoeksraad voor Veiligheid.

OvV. (2014) Kwetsbare zorg: patstelling in het Ruwaard van Putten Ziekenhuis. Den Haag: Onderzoeksraad voor Veiligheid.

Pittens, C., Zonneveld, N., Vermunt, P., \& Minkman, M. (2018). Leiderschap in alle lagen van de organisaties. Utrecht: Vilans.

Rutz, S. (2017). Practicing reflective regulation. Dissertatie, Erasmus Universiteit Rotterdam, Rotterdam.

Sabel, C.F., \& Zeitlin, J. (2008). Learning from difference: The new architecture of experimentalist governance in the EU. European Law Journal, 14(3), 271-327.

Schakel, L., \& Stoopendaal, A. (2017). De plaats van het interne toezicht in de praktijk van het externe toezicht. Tijdschrift voor Toezicht, 3, 5-15. doi:10.5553/TvT/ 187987052017008003003

Scheer, W. van der. (2018). Succesvolle bestuurders. Blog in Zorgvisie .

Schippers, E., \& Rijn, M. van. (2013). Gezamenlijke agenda VWS: 'Van systemen naar mensen'. Den Haag: Ministerie van Volksgezondheid Welzijn en Sport.

Schippers, E., \& Rijn, M. van. (2016). Goede zorg vraagt om goed bestuur. Beleidskader. Den Haag: Ministerie van Volksgezondheid Welzijn en Sport.

Schoten, S.M. van. (2015). Hospital quality systems; Unraveling working mechanism. Utrecht: NIVEL.

Spronk, S., Buijze, H., Zwietering, P., Friele, R., \& Robben, P. (2017). Ontwikkeling van een afwegingskader vertrouwen voor toezichthouders. Lessen uit de praktijk van de IGJ. Tijdschrift voor Toezicht, 3. doi:10.5553/TvT/187987052017008003004

Stoopendaal, A.M.V. (2016). Al doende leren. Een essay over de experimentele zoektocht naar toezicht op zorgbesturing door de Inspectie voor de Gezondheidszorg. Rotterdam: EUR/ iBMG.

Stoopendaal, A., \& Bouwman R. (2018). Ruimte voor vertrouwen. De dynamiek van vertrouwen in het toezicht op zorg. ESHPM, Rotterdam. 
Stoopendaal, A.M.V., \& Bovenkamp, H.M. van de. (2015a). Governance: werken met de gelaagdheid van toezicht. In H. den Uijl \& T. van Zonneveld (Eds.), Zorg voor toezicht: de maatschappelijke betekenis van governance in de zorg (pp. 102-111). Mediawerf: Amsterdam.

Stoopendaal, A.M.V., \& Bovenkamp, H.M. van de. (2015b). The mutual shaping of governance and regulation of quality and safety in Dutch healthcare. Health Service Manage Research, 28(1-2), 9-15. doi:10.1177/0951484815607542

Stoopendaal, A.M.V., \& Bree, M.A. de. (2014). Evaluatieonderzoek Systeemtoezicht op kwaliteit en veiligheid in de zorg; Fase 1. Ontwikkeling van het instrumentarium en eerste ervaringen. Rotterdam: EUR/iBMG.

Stoopendaal, A.M.V., Bree, M.A. de, \& Robben, P.B.M. (2016). Reconceptualizing regulation: Experimenting with system based regulation in Dutch healthcare. Evaluation. The International Journal of Theory, Research and Practice, 22(4), 394-409.

Stoopendaal, A.M.V., Bree, M.A. de, Robben, P.B.M., \& Keuter, F. (2014). Systeem Toezicht in de Nederlandse gezondheidszorg. Een experimentele innovatie van toezicht. Tijdschrift voor Toezicht, 5(2), 27-46.

Trommel, W.A. (2009). Gulzig bestuur. Oratie, Vrije Universiteit, Amsterdam.

Twist, M. van, Klijn, E., \& Steen, E. van der. (2013). Over hijgerigheid en lange adem. Een verkenning van de relatie tussen toezicht en media. WRR webpublicatie nr. 67. Den Haag: WRR.

Vries, F. de. (2016). Leidt transparantie tot meer vertrouwen in de toezichthouder? Oratie, Rijksuniversiteit Groningen, Groningen. Verkregen van https://www.videnet.nl/ download/?id=17775563

Zorgvisie (2018, 19 april). IGJ: persoonsgerichte toetsingsvorm positief. Verkregen van https://www.zorgvisie.nl/igj-persoonsgerichte-zorg/ 